Minsterberg, H. Psychotherapy. Pp. 40r. Price, \$2.00. New York: Moffat, Yard \& Co., 1909.

The mind may be regarded from two points of view. It is a willing subject. This is the basis of literature, art, religion. But the mind is also an association of objective facts to be explained. This is the field of psychology. Psychotherapy has the same relation to psychology that engineering has to physics. Psychology knows no indescribable elements. Volitions, emotions, etc., are all complexes of sensations. Psychology is a definite science because mental facts are parallel to brain facts, and in this way they can be scientifically described. There is no purely mental disease. Psycho-physiology is the physician's point of view. There is nothing abnormal about suggestion. There is no action which has not its opposite. Full vividness belongs only to those sensations whose channels of motor discharge are open. Actions are inhibited when their motor channels are closed. This takes place when opposing channels are held open. Suggestion proper exists only when resistance has to be overcome. No one can be hypnotized against his own will. Any one may be provided he is willing to enter into this play of imagination. To hypnotize, except in the interest of health, is criminal. The subconscious is a disposition of the physiological centers. This definition suffices for normal life, and there is no reason to change it when dealing with the abnormal. This view makes no less of suggestion and hypnotism.

The statement that every mental process involves a brain process does away with appeals to psychotherapy as proving the subconscious or the triumph of the mind over the body. Psychotherapy has no contempt for drugs. It is not a question of morals or of philosophy but of experience. Religion as a sense of a larger will often inhibits disturbances and favors health where central inhibitions interfere with the normal functions of the organism. But for psychotherapy religion must fall in line with other mental processes whose relation to health must be determined by experience. Psychical symptoms are only a fraction of the disease. It is not the function of the clergy to understand disease, physical or mental. Religious emotions often upset the equilibrium of the nervous system. Psychology is the most immediate need of the medical curriculum. Hypnotism is not as injurious as morphine or Roentgen rays. But such diseases as hysteria are not intelligible without psychology. The physician must know psychology for emotions, etc., affect the blood supply as well as drugs.

Iowa College.

J. Dashiell Stoops.

Noyes, A. D. Forty Years of American Finance. Pp. 418. Price, \$1.50. New York: G. P. Putnam's Sons, 1909.

In $1898 \mathrm{Mr}$. Noyes published his interesting and serviceable narrative of American financial history for the period 1865 to 1897 . His new book is the older work rewritten with a continuation of the narrative down through the panic of 1907 . Mr. Noyes notes in his preface that he has made no 
important changes in the facts and conclusions found in the earlier book, except that in his later work he does not ascribe to John Sherman sole authorship of the Resumption Act nor responsibility for its defects. (p. 27.)

After a very brief treatment of the Gold Standard Act of 1900 , the author begins the new part of his book with a chapter on the tremendous industrial boom which marked our recovery from the effects of the panic of I893. The remarkable and significant increase in the world's output of gold, the marked rise in prices, especially of agricultural products, between 1897 and I900, the victory of the gold party, the Dingley tariff, the "American Invasion," railway reorganization, the Spanish and Boer Wars are dwelt upon in this chapter. The amalgamation of companies, the manipulation and multiplication of new industrial stocks, and the rich man's panic of rgo3, are factors of the chapter on the speculative mania of rgor. The advancing cost of living, the growing strain on capital, the financial significance of the Russian-Japanese war, high money rates and predictions of impending disaster, trust manipulators, the New York life insurance investigations, the Northern Securities case, the $\$ 29,000,000$ fine, and the Hepburn law, are the subjects found in the next three chapters. The book closes with an interesting twenty-six page exposition of the panic of 1907.

Mr. Noyes has necessarily taken up a large number of factors bearing on the financial period 1896 to 1907 , in his one hundred and twenty-four moderately sized pages; many would prefer a fuller discussion of some of these factors, others will perhaps be glad of the author's brevity. However that may be, Mr. Noyes has written a very interesting and serviceable narrative of a period of American finance marked by movements and events full of the greatest significance to the American people.

\section{University of Minnesota.}

Raymond V. Phelan.

\section{Peyton, J. H. The Amertcan Transportation Problem. Pp. 204. Price, 50 cents. Louisville: Courier Journal Publishing Company, roo8.}

This book deals exclusively with the movement for improved inland waterways. The author begins his arraignment by charging that the movement is "based on prejudice and lack of information as to actual transportation conditions and developments." This prejudice, he claims, is due largely "to the misrepresentations by venal demagogues and socialistic agitators who obtain office and preferment by stirring up bitterness and hatred between different classes of society." To brand the friends of inland waterways, many of whom are wholly removed from politics and some of whom are prominent railroad men, with such intentions at once discloses the bias which pervades the whole book. The modern improvement of inland waterways he likens to the South Sea and Mississippi Bubbles; the plans of engineers favoring reservoirs, he says, "though amusing, grow wearisome in the superabundance of absurdities." European waterways and government railways he pronounces unqualified failures, upon the authority of Hugo R. Meyer, who, 